LUONG MINH CHINH

Transportation Department, Civil Engineering Faculty,

Thuy Loi University, Hanoi, Vietnam.

e-mail: chinhlm@tlu.edu.vn
Manuscript submitted 2019.09.02 - revised 2019.09.20,

initially accepted for publication 2019.09.23, published in September 2019

\title{
ANALYSIS AND ASSESSMENT OF EXISTING STRUCTURAL HEALTH MONITORING SYSTEMS (SHMS) OF CABLE-STAYED BRIDGE IN VIETNAM
}

\section{ANALIZA I OCENA ISTNIEJĄCYCH SYSTEMÓW MONITOROWANIA STANU STRUKTURALNEGO (SHMS) MOSTU WANTOWEGO W WIETNAMIE}

\author{
DOI: $10.30540 /$ sae-2019-014
}

\begin{abstract}
Since 2000 when the My Thuan Bridge, the first cable-stayed bridge in Vietnam, was put into operation, and now Vietnam has more than 20 types of cable-stayed bridges constructed throughout the country in the last two decades, which is a significant accomplishment for a developing country like Vietnam. Therefore, the SHM system is gradually being designed and installed for cable stayed bridges to ensure economic exploitation and safety. Due to the limited of financing sources, these systems are very limited, and their quality have a lot to be desired. Also, due to the lack of appropriate classification personnel with experience in the SHM system, these systems encountered a lot of problems. In this article author will deeply analyze the mistakes and problems of these SHM systems, which already exist in Vietnam, to find solutions for the future. Therefore, this will open up new prospects, new challenges and possibilities for the development of these systems in Vietnam in the near future.
\end{abstract}

Keywords: SHM system, concrete cable-stayed bridge, monitoring system, AE sensors, cracks

\begin{abstract}
Streszczenie
W 2000 roku oddano do uzytku most My Thuan, pierwszy most wantowy w Wietnamie. Na chwile obecna Wietnam ma ponad 20 rodzajów mostów wantowych zbudowanych w calym kraju w ciagu ostatnich dwóch dekad, co jest znaczacym osiagnięciem dla kraju rozwijającego się. W zwiazku z tym system SHM jest stopniowo projektowany i instalowany dla mostów kablowych, aby zapewnić ekonomiczna eksploatację i bezpieczeństwo. Ze względu na ograniczone źródta finansowania systemy te sa bardzo ograniczone, a ich jakość pozostawia wiele do życzenia. Ponadto z powodu braku odpowiednio wykwalifikowanego personelu z doświadczeniem w systemie SHM systemy te napotkaty wiele problemów. $W$ tym artykule autor dogłębnie przeanalizuje błędy i problemy systemów SHM, które już istnieja w Wietnamie, aby znaleźć rozwiąania na przyszlość. Otworzy to nowe perspektywy, nowe wyzwania i możliwości rozwoju tych systemów $w$ Wietnamie.
\end{abstract}

Słowa kluczowe: System SHM, betonowy most wantowy, system monitorowania, czujniki AE, pęknięcia

\section{INTRODUCTION}

The SHM system for bridges, Andersen et all (2006), has recently been considered for installation on a few cable-stayed bridges in Vietnam due to their sensitivity to the structural load. On April 10, 2012 the Ministry of Transport has sent Official Letter 2727/BGTVT-KCHT, which regulates "Hanging suspension (suspension bridge, cable-stayed bridge) shall be installed monitoring system", to Directorate of Roads of Vietnam. According to this regulation the special bridge construction (the maximum span length $>150 \mathrm{~m}$ high or $>50 \mathrm{~m}$ high) is required to have a monitoring system, Chinh (2014). 
Bridge projects in Vietnam, which have already installed monitoring systems, are: Bai Chay bridge (Shimizu system during construction and it is no longer in operation, the new system was installing during the exploitation phase by ADVITAM); Rach Mieu Bridge (SHMS built by VSL and TEDI to supervise the construction process), B.H. Huong (2014); The Can Tho Bridge (SHMS by NTT Data -BRIMOS); The Binh Bridge, Hai Phong (VSL and VITEC Engineering); The Rao II Bridge, Hai Phong (MTH and Savcor); The Nhat Tan Bridge (VSL has been installed during the construction phase and the operating station is now operational), Kien Bridge and My Thuan Bridge are being installed, Chinh (2016).
The reality is that the SHM systems installed in Vietnam are quite diverse and currently there are no common regulations, requirements for them from the regulatory authorities. SHM systems are implemented by many different vendors with devices from various suppliers with different number of sensors, quality and cost. The purposes of system design are not consistent. During the exploitation phase of each bridge, the operating unit develops a maintenance manual or maintenance manual, regulations on data, however, the reporting regime is still unclear, lacks of unity and the maintenance requirements are not detailed that leads to difficulties in usage and operation of these new systems, Chinh (2014).

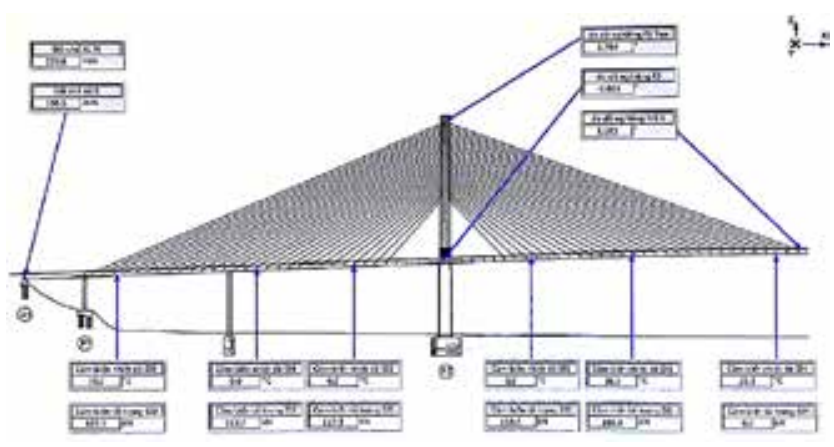

Fig. 1. Main screen of SHMS Bai Chay's Bridge (Advitam)

Table 1. Current devices status of Bai Chay bridge SHM system

\begin{tabular}{|c|c|c|c|c|}
\hline No & Device & Quantity & Status & Location \\
\hline 1 & Measure the wind & 1 set & Normal & On top of P3 pylon (Fig. 2) \\
\hline 2 & Weather station & 1 set & Normal & Middle of main span (Fig. 2) \\
\hline 3 & Traffic flow monitoring camera & 4 & Normal & P3 pylon \\
\hline 4 & Vehicle Weight In Motion system (WIM) & 1 set & Normal & $10 \mathrm{~m}$ from $\mathrm{A} 1$ abutment (Fig. 3 ) \\
\hline 5 & Earthquake monitoring & 1 set & Normal & A1 abutment \\
\hline 6 & Measure the tilt of pylon & 1 set & Normal & P3 \\
\hline 7 & Measure the rotation of girder & 2 set & Normal & Segment $K_{0}$ at $P 3$ \\
\hline 8 & Measure the deformation and pylon stress & 8 set & Normal & P3 pylon \\
\hline 9 & Measure the deformation and stress of girder & 12 set & Normal & In the box girder \\
\hline 10 & Measure the oscillation of pylon & 2 set & Normal & P3 \\
\hline 11 & Measure the oscillation of girder & 2 set & Normal & P3 \\
\hline 12 & Measure the oscillation of cable & 4 set & Normal & Cable ( $\mathrm{P3}$ side) \\
\hline 13 & Measure the temperature of cable & 6 set & Normal & Cable (P3 side) \\
\hline 14 & Measure the tension of cable & 6 set & Normal & Cable ( $\mathrm{P3}$ side) \\
\hline 15 & Lightning rod & 2 set & Normal & Al, middle of span \\
\hline 16 & Backup Power and Data Backup & 1 set & Normal & Monitoring station \\
\hline 17 & Monitoring station & 1 & Normal & \\
\hline
\end{tabular}




\section{EXISTING MONITORING SYSTEMS IN VIETNAM}

\subsection{Bai Chay Bridge SHM system}

During the construction of the Bai Chay Bridge, a monitoring system has been installed for the construction phase (by the Contractor Shimizu). However, the system is no longer active (due to a fire inside the bridge box girder). During the construction phase, the data has been sent directly to Research Centre of Shimizu in Japan for analyzing and making necessary adjustments to the construction work. The measurement data during the construction phase is stored by Shimizu and not shared with current management unit.

New monitoring system for the operation phase has been installed by ADVITAM, completed and activated since 2014, but due to limited budget, the system is only installed on one side of the P3 pier. Therefore, the assessment of the overall condition of the structure faces a lot of difficulties. The data collection maintenance is implemented by ADVITAM (during a 5-year warranty, while the other bridges' warranty). However, the company does not have a representative in Vietnam, so the technical support will be a challenge. All system modifications must be made by ADVITAM - this is a restriction that leads to a lack of flexibility of the system.

The bridge management unit concurrently operates the monitoring system, however, it is incapable of analyzing and evaluation of data for assessment and maintenance of the bridge. Also, there is no analysis of the data reported.

There should be a collaboration with experts from universities and research institutes in data analysis and evaluation as well as the possibility of upgrading
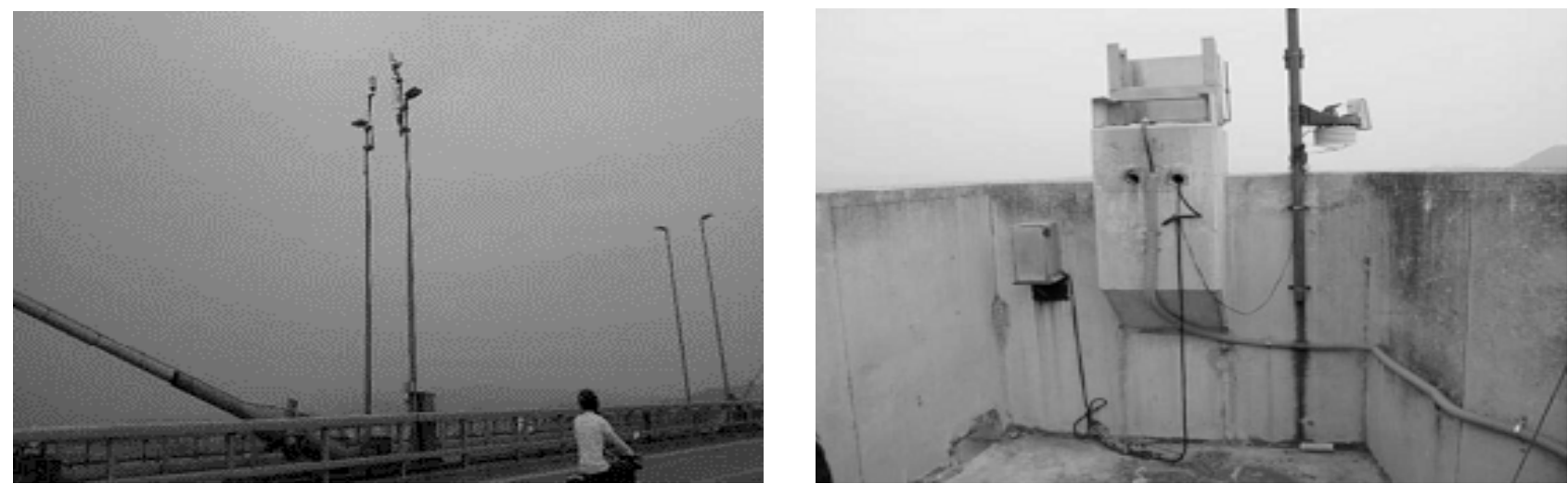

Fig. 2. Weather station install in main desk and on the top of pylon anchor of Bai Chay Bridge

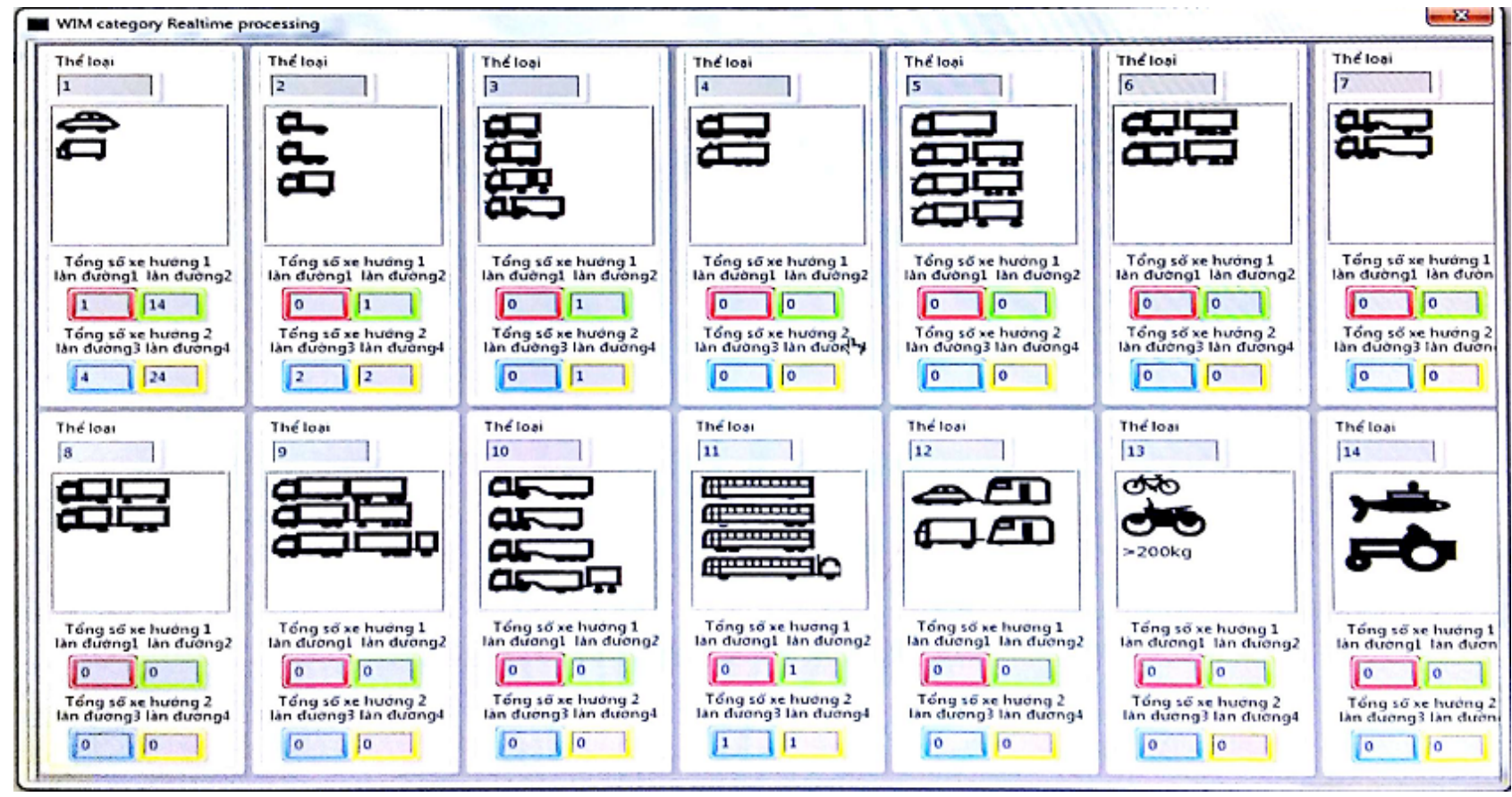

Fig. 3. WIM screen of SHMS Bai Chay's Bridge 
existing monitoring systems shall be considered. There should be also a full transfer from ADVITAM for equipment control, software and results of analysis for the data management and analysis unit. Due to the complexity of the Bai Chay bridge structure and the subjects that need frequent monitoring such as bearings displacement, in addition to the regular inspection and monitoring system, other periodical monitoring is required in order to fully assess the current status of the structures.

\subsection{Binh Bridge SHM system}

In 2010, an incident occurred to Binh Bridge in Hai Phong. The CONSON hurricane broke off the anchors of three large ships anchored at Bach Dang Shipyard, about $500 \mathrm{~m}$ from bridge and they all went downstream, crashing into Binh bridge's girder causing damage at main girder (Fig. 4) and two cables, leading to stopping the traffic for vehicles over 3.5 tons until the repair works completed.

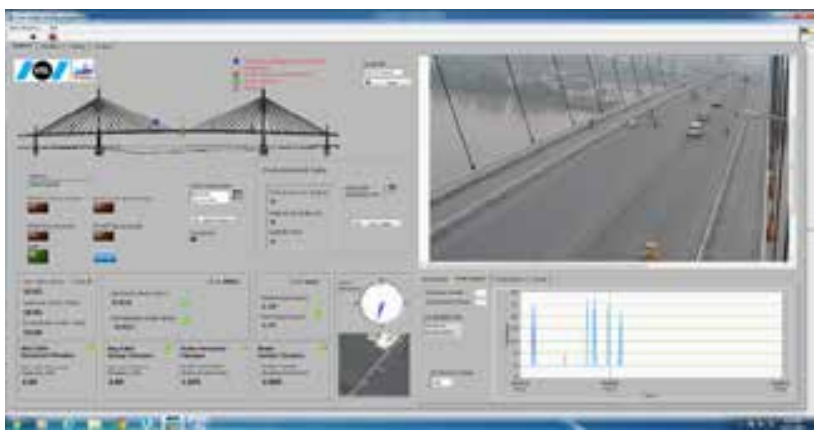

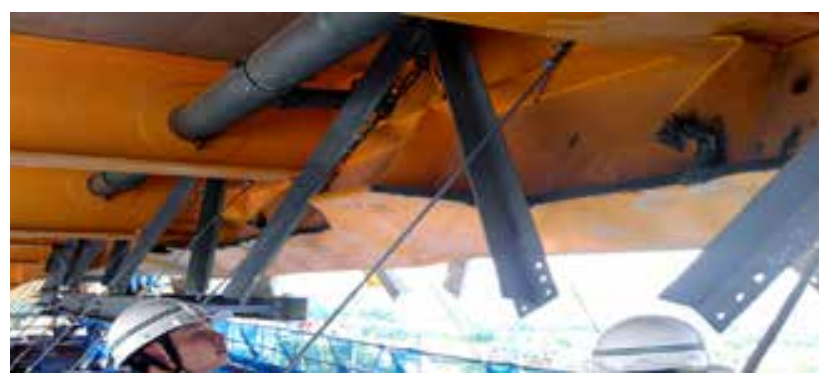

Fig. 4. Main girder deformation after the ship collision with Binh Bridge during CONSON hurricane

In 2012, repair and rehabilitation work was carried out and a monitoring system (phase 1) was established for the purposes: regular monitoring of the operation phase (analysis the behavior of the special structure to assess the behavior under the influence of wind load and weather conditions), support maintenance work for early warning of any abnormal states, as well as to make accurate recommendations on upgrade, maintenance and to recheck design assumptions (Fig. 5).

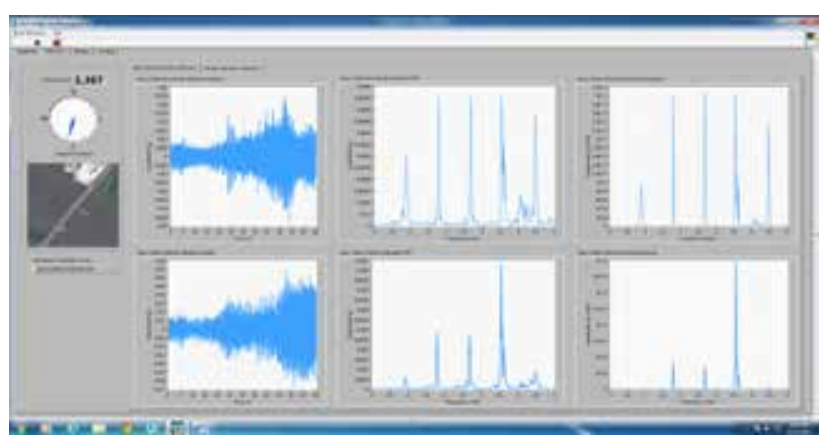

Fig. 5. Main screen of and vibration measurement screen Binh Bridge SHMS by VSL and VITEC

Table 2. Binh Bridge SHMS equipment status

\begin{tabular}{|c|l|c|c|l|}
\hline No & \multicolumn{1}{|c|}{ Device } & Quantity & Status & \multicolumn{1}{|c|}{ Note } \\
\hline 1 & Wind speed and direction & 1 set & Normal & Middle of main span \\
\hline 2 & Weather station & 1 set & Normal & On deck slab near S9 \\
\hline 3 & Traffic flow monitoring camera & 1 set & Normal & S9 pylon \\
\hline 4 & Measure the oscillation of girder & 1 set & Normal & Middle of main span \\
\hline 5 & Measure the oscillation of cable & 1 set & Normal & C20 \\
\hline 6 & Measure the temperature of cable & 1 set & Normal & Cable C20 \\
\hline 7 & Measure the temperature of girder & 1 set & Normal & S9 pylon \\
\hline 8 & Measure the deformation of girder & 1 & Normal & Figure 6 \\
\hline 9 & Monitoring station & & \\
\hline
\end{tabular}

Due to limited budget, the minimum option for system has been selected. The basic equipment, that has been installed, will be combined with regular inspection and monitoring on an annual basis to evaluate the current situation of Binh Bridge after rehabilitation. At the time of survey, all devices were working normally (Fig. 6). 

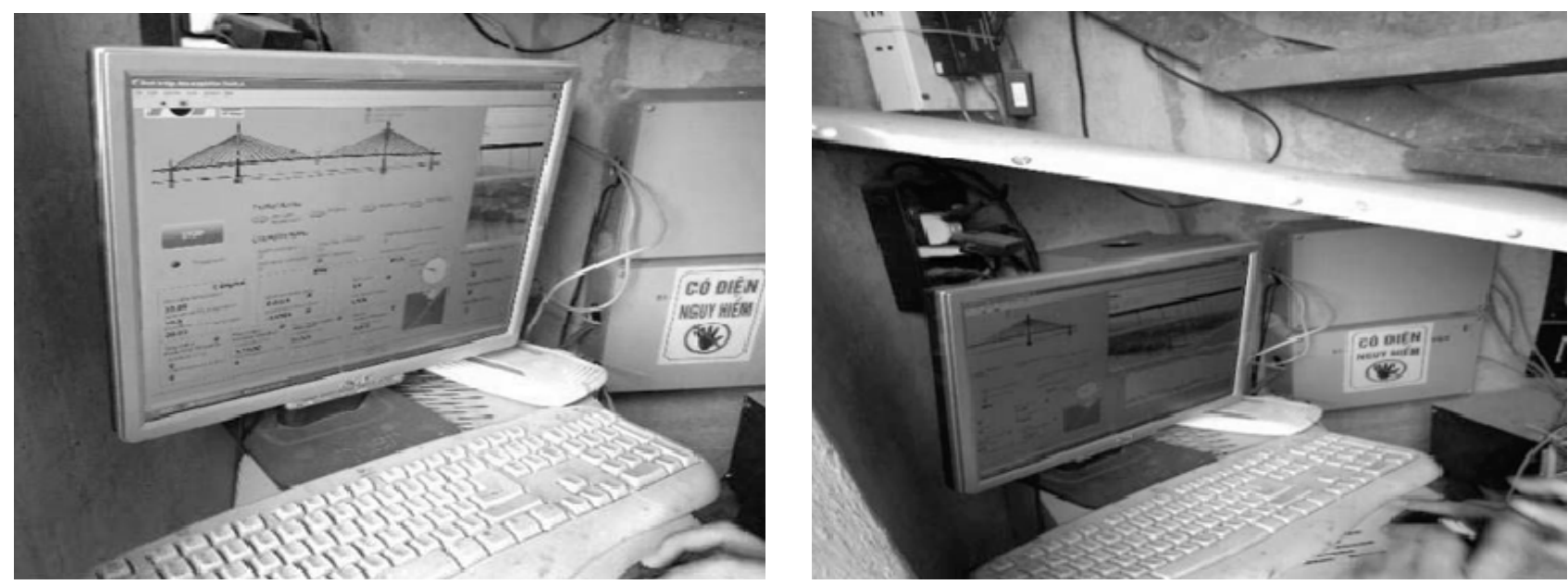

Fig. 6. Data equitation using normal PC computer install inside the pylon of Binh Bridge

SHM of Binh Bridge system has some advantages and disadvantages as follows:

- New monitoring system of Binh bridge is very simple with fewer sensors in order to provide some basic warning on tension in the longest cable, girder oscillation, traffic, weather, etc., which do not help in the assessment of the current status of the structures.

- The supplier has an office in Vietnam, which allows a quick technical support; modern equipment and software have a Vietnamese interface with full basic information.

- System management unit is incapable for in-depth analysis of data in order to make assessment and maintenance of the bridge and have no data for analysis reports.

- It should be upgraded to a complete monitoring system that can fully assess the current status of the structure (Level 3, 4).
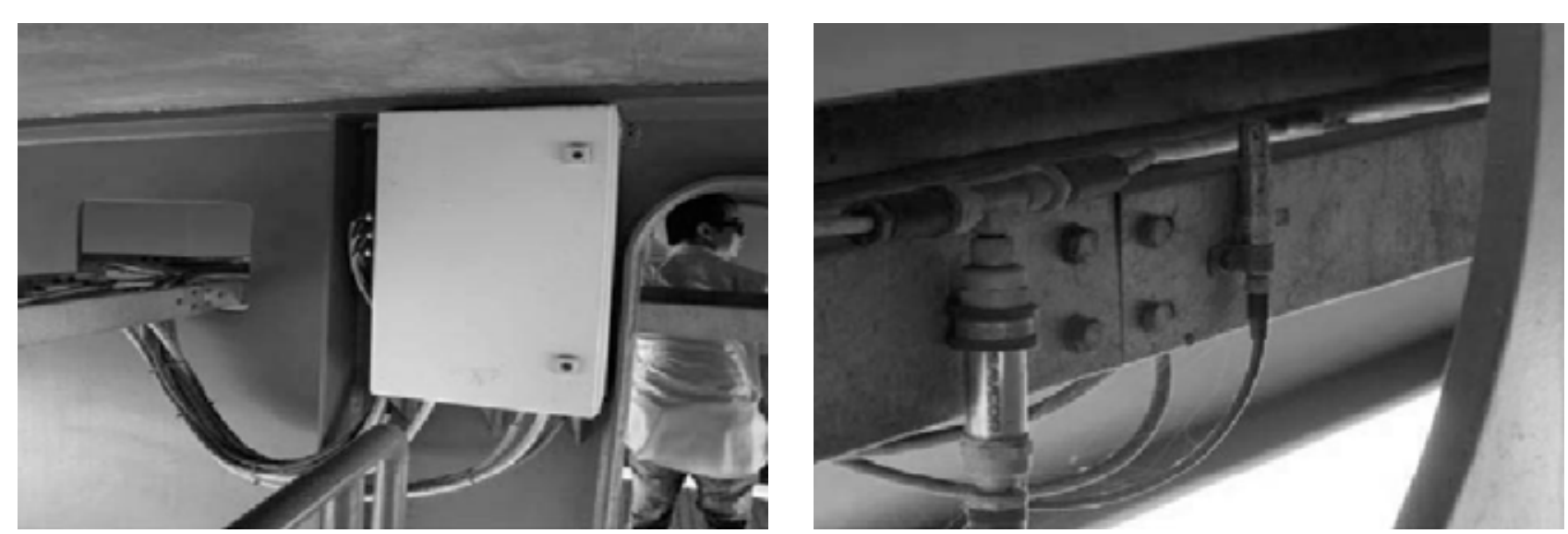

Due to the complexity of Binh bridge structure, that previously has had an incident and the bridge was once repaired, in addition to the regular inspection and monitoring system, other periodical monitoring is required to fully assess the current status of the structures in order to avoid future incidents.

\subsection{Rao Bridge II SHM system}

A monitoring system has been installed for Rao Bridge II in Haiphong in 2012, by the end of construction works, for monitoring in operation phase. This is a relatively complete system and if integrated with proper analytical software can help assess the structural status. The cost of the system is lower than some similar systems in Vietnam. But at the time of the survey the system was not active, awaiting repair (Table 3 ).

Fig. 7. Temperature sensor install on main girder of Rao II Bridge during inspection 
Table 3. Current devices status of Rao 2 bridge SHM system

\begin{tabular}{|c|l|l|l|c|}
\hline No & \multicolumn{1}{|c|}{ Devices } & \multicolumn{1}{|c|}{ Value } & Operation & Normal \\
\hline 1 & HI-2 & Humidity and temp. & At the abdomen, anchor tunnel & Normal \\
\hline 2 & H3-4 & Humidity and temp. & Top of the pylon & Normal \\
\hline 3 & H5 & Humidity and temp. & In the middle of main span & Normal \\
\hline 4 & W1 & Weather station & Top of the pylon & No signal \\
\hline 5 & D1-D2 & Transposition & Expansion joint & No signal \\
\hline 6 & D3 & Transposition & Top of the pylon & No signal \\
\hline 7 & D4 & Transposition & C15 & No signal \\
\hline 8 & Accl & Acceleration, 3 dimensions & C15 & No signal \\
\hline 9 & Acc2 & Acceleration, 3 dimensions & Top of the pylon & No signal \\
\hline 10 & Acc3, Acc4 & Acceleration, 3 dimensions & Stay cable & No signal \\
\hline 11 & Sgl-4 & Stress measurement & Near anchor abutment & No signal \\
\hline 12 & SgS-8 & Stress measurement & Near the second cable & No signal \\
\hline 13 & Sg9-Sgl6 & Stress measurement & Reinforced steel pillar at the elevated pillow position & Normal \\
\hline 14 & Cam 1-4 & Traffic monitoring & On the pylon & Normal \\
\hline 15 & D3R-D4R & Mirrors & Top of the pylon & \\
\hline
\end{tabular}

In fact, there was a problem and has been fixed in the warranty period covered by foreign supplier. However, at the moment, the warranty period has expired and the support from the supplier has been stop. At the time of inspection, the main sensors did not transmit the signal to the center. The supplier is abroad so should be late in technical support, maintenance; the warranty period is expired and no solution have been taken. System management unit is incapable for in-depth analysis of data in order to make assessment for bridge maintenance and inspection to troubleshoot. It has no data for analysis report. Then the SHM system needs to be repaired and put back into operation as soon as possible.

\subsection{Can Tho Bridge SHM system}

Can Tho Bridge installed a SHM system - BRIMOS (Fig. 8), Chinh (2014), in operation phase from the end of 2013 with the purposes: to provide data for analysis and to evaluate the structural condition through the behavior of the bridge structure (Fig. 9). Use of monitoring data to manage (control) traffic safety and flow in abnormal conditions as well as provide design check data.

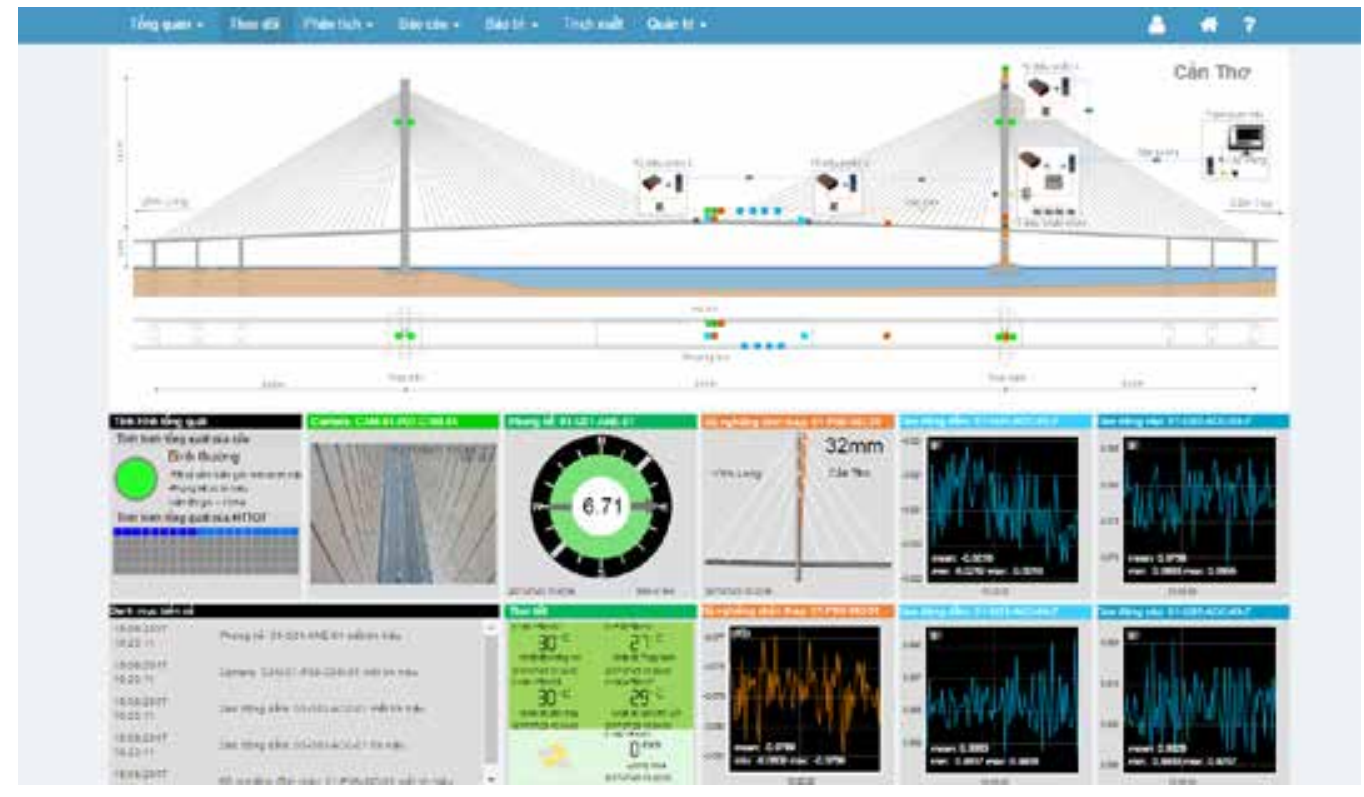

Fig. 8. Main screen of the SMH system of Can Tho Bridge 

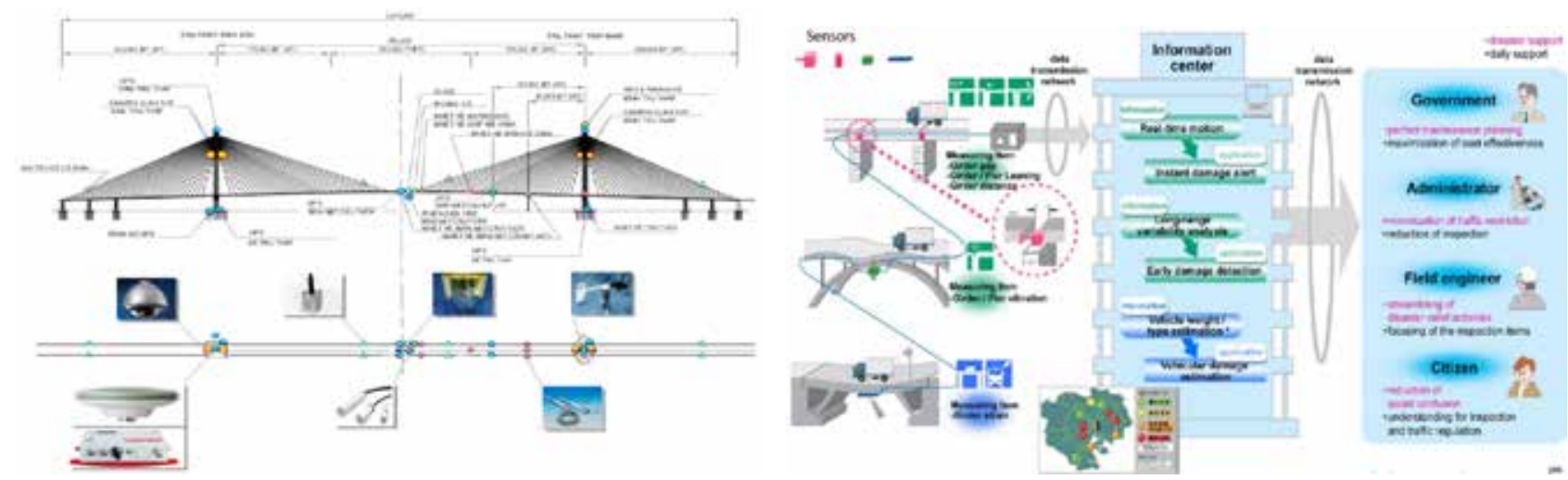

Fig. 9. Schematic of sensors installation of SHMS Can Tho's Bridge (left) and BRIMOS diagram.

Table 4. Can Tho Bridge continuous monitoring equipment

\begin{tabular}{|c|c|c|c|c|}
\hline No & Devices & Measuring category & Quantity & Status \\
\hline \multirow{6}{*}{1} & \multirow{6}{*}{ Temperature } & Air temperature & 1 & Normal \\
\hline & & Steel slab temperature & 4 & Normal \\
\hline & & Prestressed concrete slab temperature & 4 & Normal \\
\hline & & South pylon temperature & 4 & Normal \\
\hline & & Joints temperature & 4 & Normal \\
\hline & & Monitoring cable temperature & 1 & Normal \\
\hline 2 & Wind speed and direction & Speed / Direction & 2 & Normal \\
\hline 3 & Rain gauge & Rainfall & 5 & Normal \\
\hline 4 & GPS & Different displacements & 6 & Normal \\
\hline 5 & CCTV & Bridge's conditions & 4 & Normal \\
\hline 6 & Handheld accelerometer & Oscillation characteristics & 3 & Normal \\
\hline 7 & Deformation & Deformation of steel slab & 8 & Normal \\
\hline 8 & Fixed accelerometer & Induction oscillator cable & 8 & Normal \\
\hline
\end{tabular}

At the time of survey, the monitoring equipment was working normally, transmitting raw data to Can Tho bridge maintenance department. The SHM system send daily reports about its status, but doesn't have detailed analysis of the data due to the incapable of management unit to analyze and evaluate the data. It happened that due to the high frequency of data collection, much higher data leads to memory overflows and the system automatically erase old data, leading to the loss of essential information.

In addition, the system of Can Tho Bridge has some advantages and disadvantages as follows:

- Supplier of the BRIMOS system is NTT DATA, Chinh (2014), a leading IT company in Japan but has not experienced in developing bridge monitoring systems - although BRIMOS is a relatively complete system, but for the first time it has been applied in Vietnam, therefore it has many restrictions. The cost of the system is quite high compared to similar systems in Vietnam.
- GPS data in global coordinates has not yet been transferred to the local coordinates leading to ineffective use, dynamic analysis data has not generated the oscillation frequency of the structure. High frequency of data collection lead to memory overflow.

- The system is installed in the operation phase, so the initial data of status " 0 " is missing.

- The supplier is abroad so there will be difficulties in technical support, maintenance if any.

- System management unit is incapable for in-depth analysis of data in order to make assessment for bridge maintenance.

To overcome the disadvantages mentioned above, there should be consider the ability to upgrade the software especially for the processing of GPS data to exclude unnecessary duplication of raw data in order to effectively evaluate structure status. 


\subsection{Nhat Tan Bridge SHM system}

Nhat Tan Bridge monitoring system has been installed in construction phase in 2015, which has been handed over and put into operation. The Nhat Tan Bridge is located on the new route from Noi Bai new international airport to downtown in Hanoi, Vietnam.

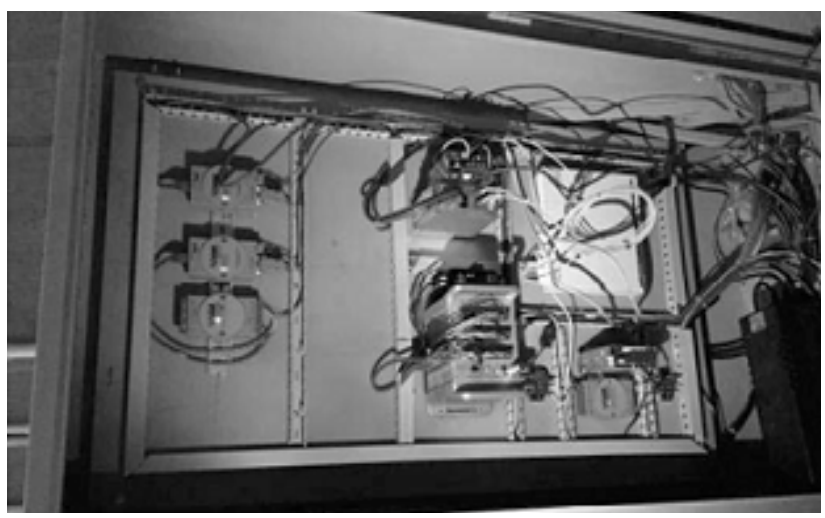

The bridge opened to traffic in January 2015. The main bridge is a $1500 \mathrm{~m}$ long, 6-span cable stayed bridge with 8 traffic lanes. This scale of multiple span cable stayed bridge is the first application in Southeast Asia and also very rare type of bridges in the world, K. Matsuno \& N. Taki (2014).

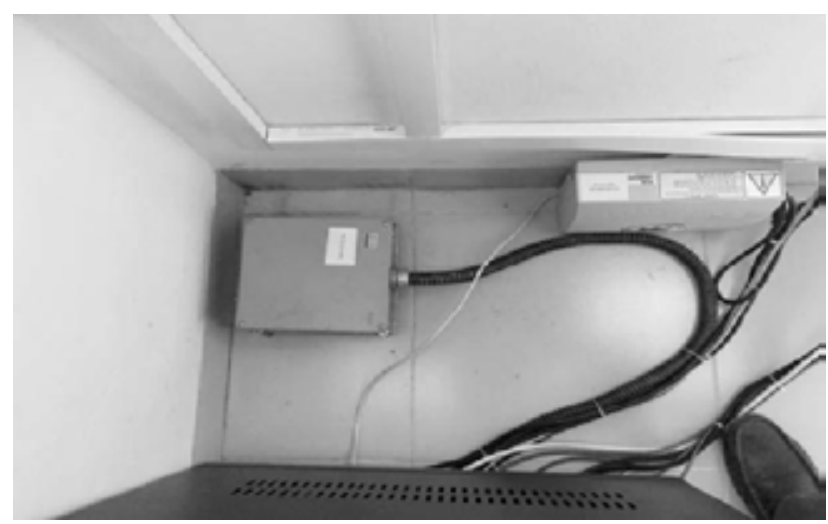

Fig. 10. Installation of SHM system of Nhat Tan Bridge (left) and seismic sensor (right)

Table 5. Basic components of Nhat Tan Bridge SHM system

\begin{tabular}{|c|l|c|c|}
\hline No. & \multicolumn{1}{|c|}{ Device } & Quantity & Status \\
\hline 1 & System of deformation of main beams and towers & 18 & Normal \\
\hline 2 & Measurement Instrument for the pylon & 6 & Normal \\
\hline 3 & Measurement instrument for cable oscillation & 3 & Normal \\
\hline 4 & Measurement instrument for cable tension & 20 & Normal \\
\hline 5 & Measurement instrument for pylon temperature & 40 & Normal \\
\hline 6 & Measurement instrument for surface temperature & 15 & Normal \\
\hline 7 & Measurement instrument for cable temperature & 4 & Normal \\
\hline 8 & Measurement instrument for deformation of the beam & 80 & Normal \\
\hline 9 & Measurement instrument for ambient temperature & 8 & Normal \\
\hline 10 & Measurement instrument for the wind & 1 & Normal \\
\hline 11 & Measurement instrument for rainfall & 1 & Normal \\
\hline 12 & Measurement instrument for seismic incidents & 2 & Normal \\
\hline
\end{tabular}

Nhat Tan Bridge SHM system has been installed in the construction phase, with a large number of sensors, some highly effective measuring cumulative values of construction, such as cable tension and deformation sensors. The system has the most number of sensors. Investment cost is also the highest among systems that have been installed in Vietnam. But adjusting and defining the initial value along with warning thresholds is difficult. At the time of survey, the monitoring equipment was working normally.

System management unit is incapable for in-depth analysis of data in order to make assessment for bridge maintenance and inspection to troubleshoot. There is no data for analysis report.

\section{OVERALL ASSESSMENT ON CURRENT SHM SYSTEMS IN VIETNAM}

SHM system designed and installed in Vietnam are quite diversified. They were provided by various consultants and came with different quality and cost from many vendors. The determination of the purpose and system building method, analysis and evaluation and use of data are not regulated and specifically guided from state management agencies, so, the 
comparison and evaluation are relatively complicated. This section provides some basic assessments based on the criteria mentioned above.

Almost all SHM system have ambiguous purpose and the level of monitoring to be achieved has not been determined. The fact that the SHM system, which have been designed and installed in Vietnam, often includes a wide range of categories and various measurement sensors, at very high cost, may be at the maximum price. While to ensure economic and technical efficiency, it is also necessary to determine the appropriate minimum level for each type of bridge according to the decentralization of the project and the current status of the project towards the achievement of a higher level of monitoring. Those systems surveyed are only at level 1, that means, only some basic raw information are provided with some additional warning messages, but warning thresholds are not accurately and clearly defined. But up to now, the targets set for these monitoring systems have not been fully defined. Selection of monitoring system components is relatively diverse, depending on the design unit as there are no general regulations, Chinh (2014).

Table 6. Comparison of SHM system of Bai Chay Bridge and Can Tho bridge (main items)

\begin{tabular}{|c|l|c|c|c|}
\hline No & \multicolumn{1}{|c|}{ List of equipment } & Bai Chay & Can Tho & Remarks \\
\hline 1 & Weather, wind measurement station & 2 sets & 3 sets & - \\
\hline 2 & Earthquake monitoring & 1 set & 10 sets & abutment A1 - BC \\
\hline 3 & GPS & 4 pieces & 4 pieces & \\
\hline 4 & Traffic flow monitoring camera & 1 set & - & Pier P3 - BC \\
\hline 5 & Weighing In Motion system & 1 set & GPS & \\
\hline 6 & Tower incline measurement instrument & 2 sets & GPS & \\
\hline 7 & Girder rotary angle measurement instrument & 8 sets & - & \\
\hline 8 & Pylon tower deformation measurement instrument & 12 sets & - & \\
\hline 9 & Girder deformation measurement instrument & 4 sets & 4 sets & \\
\hline 10 & Girder, tower fluctuation measurement instrument & 6 sets & - & \\
\hline 11 & Cable fluctuation measurement instrument & - & 1 & \\
\hline 12 & Cable tensioning force measurement instrument & & & \\
\hline 12 & Manual accelerometer & sets & \\
\hline 13 & Monitoring station & & \\
\hline
\end{tabular}

Ability of provision of information of SHM system installed is also very diverse. The accuracy of the equipment is also a matter for periodic inspection and calibration. Analysis ability of the current software limits the processing capabilities and further analysis. Many of the data are provided in crude form, especially GPS, oscillation data. Management staff do not have an in-depth knowledge of data analysis and assessment, so the daily reports are mostly just the current status of the operation of the equipment. Initial assessment of the ability to provide information on structural behavior at five levels, Chinh (2015), of monitoring at the bridges with installed SHM system (Table 7).

Table 7. Evaluation of installed SHM system by monitoring level

\begin{tabular}{|c|l|l|c|l|}
\hline No & Bridge & \multicolumn{1}{|c|}{ SHM System } & $\begin{array}{c}\text { Current } \\
\text { monitoring level }\end{array}$ & \multicolumn{1}{|c|}{ Ability of improvement to achieve level 3,4 } \\
\hline 1 & Bai Chay & In operation stage & Level 1 & $\begin{array}{l}\text { Need to complete software and calculation model with an update of monitoring } \\
\text { data. The difficulty of this system is that the monitoring system is only installed } \\
\text { on tower P3 }\end{array}$ \\
\hline 2 & Can Tho & In operation stage & Level 1 & $\begin{array}{l}\text { Need to complete software and calculation model with an update of monitoring } \\
\text { data }\end{array}$ \\
\hline 3 & Binh & In operation stage & Level 1 & Need to supplement in second stage \\
\hline 4 & Rao II & In construction and operation stage & Level 1 & The system has stopped working, need to be rectified \\
\hline 5 & Nhat Tan & In construction and operation stage & Level 1 & $\begin{array}{l}\text { Need to complete software and calculation model with an update of monitoring } \\
\text { data }\end{array}$ \\
\hline
\end{tabular}


Ability of provision of bridge traffic information -At now the bridge cameras are one of the most effective items in monitoring of traffic flow, accident handling, bridge protection, with sufficient number that can scan throughout the bridge. It is necessary to supplement monitoring radar and traffic count equipment to measurement number, type of vehicles and speed, etc., and combine with WIM that can weigh and determine the load, to restrict overload vehicles.

Ability of provision of information on weather, environmental condition - Information on temperature, humidity, wind direction and wind speed are fully provided. However, the association of these parameters with structural behavior analysis due to the influence of ambient temperature has not been fully conducted.

Warning ability - SHM system installed in Vietnam have set up operational warning systems. However, the determination of values beyond the threshold (warning value) is difficult and in fact, these thresholds are not working effectively. It is possible to apply measurement results obtained during bridge load testing in conjunction with theoretical calculations on the model to establish the required thresholds.

Ability of standardization of structural model This is the third level that SHM system can reach. In addition, data collection process needs to be long enough (about 3 to 5 years) and in association with experienced experts.

Ability of determination of damaged location, abnormal status of work - These are the highest range of level 4 (state control) and 5 (defect detection) that SHM system can achieve. Achievement of state control is necessary and should set a goal for cable stayed bridge monitoring system. Other applications such as Acoustic Emission (AE) should be applied in detecting damages and damaged locations, especially for reinforced concrete bridges, Chinh et al (2015).

Ability of forecast, assessment of structure working life - This is the highest threshold that the monitoring system can achieve, Friswell et all (1995). The system can forecast working life of the work and many algorithms are now under development in the world to reach this level in order to:

- Support to determine the remaining life of the structure.

- Forecast damage, abnormal status.

- Support to make timely maintenance or preservation.

Ability of combination with other maintenance works - The installed SHM system have initially supported maintenance work. It even reduced many maintenance costs, removed periodical inspection work in many bridge works. However, it should be noted that the SHM system cannot replace the maintenance work, and should be combined with other inspection work to fully assess the current status of the work.

Durability and working life of the system - Sensors have a relatively good working life span (over 5 years), but problems often occur with data transfer connections that results in system malfunction. This is noteworthy as it will affect the continuity and accuracy of the data. The sensors located in concrete have high risk because they cannot be replaced. Particularly, in Rao 2 Bridge, after 2 years of operation, the system has stopped waiting for repair.

Economic criteria - Currently, according to the world's statistics, the current SHM system cost is about $0.3-1.5 \%$ of total investment cost. Cost of SHM system in Vietnam are very high. SHM system of Can Tho bridge has a big number of sensors, especially GPS, and the cost of this system can be up to 1 million USD (total investment cost is more than 200 million USD).

\section{CONCLUSION}

The study has proposed criteria and specification for technical and economic assesment on the basis of Vietnam conditions, including 11 technical criterias and 1 economic criteria. SHM system have been installed on 07 typical cable stayed bridges. SHM system of each bridge has been analyzed to show the advantages and disadvantages, operation situation, practical effect, oustanding works and propose specific rectification solutions to help the management units to learn from experience and have timely rectification.

Cable stayed bridge structure is a completed structure. Its behavior, dependent on frequent and random loads and effects, is very difficult to verify. So, it is more difficult to control by conventional measures. In some cases, the design, construction, quality control work, etc. fully comply with legal documents, technical regulations, relevant standards, etc. but in construction, operation, exploitation process, etc., technical problems, even collapse of works still occurs.

Therefore, the installation of SHM system is necessary to solve the above problems. However, SHM system in Vietnam still has many problems and is not managed consistently. The installation of the SHM system has been individually and spontaneously 
carried out in a number of projects, largely dependent on the capital source and subjective opinions of consultants and contractors. The owner and management unit do not have much experience in this sector. The management, analysis, processing and storage of data and parameters collected from monitoring systems in the exploitation process in many works is perplexed, not effective and the number of experts is limited.

\section{REFERENCES}

[1] Huong B. H., 2014. Bố trí thiết bị quan trắc cho cầu dây văng Rạch Miễu-Tạp chí Cầu-Hầm, TEDI/Bộ GTVT.

[2] Friswell, M.I. and Mottershead, J.E. (1995), Finite Element Model Updating in Structural Dynamics, Kluwer Academic Publishers. ISBN 978-94-015-8508-8.

[3] Nam H., 2018. Hệ quan trắc công trình cầu Cần Thơ - Tạp chí Giao thông vận tải, ISSN: 2354-0818

[4] Andersen J. E., Vesterinen A., 2006. Structural Health Monitoring Systems - First Edition. COWI - Futurtec COWI ISBN-87-91044-04-9.

[5] Matsuno K. \& Taki N., 2014 - Construction of the Nhat Tan (Japan Vietnam Friendship Bridge) Superstructure. Bridge and Foundation Engineering Vol.48: 02-12.

[6] Chinh L. M., 2014. BRIMOS - SHM system for cable-stayed Can Tho Bridge, Inżynieria I Budownictwo - ISSN 0021-0315. Poland. No 7/2014:.397-400.

[7] Chinh L. M., 2014. Long term structural health monitoring system for cable stayed bridge in Vietnam. Tap chi Khoa học kỹ thuật thủy lợi và Môi truờng - ISSN: 1859-3941. No. 44 (3/2014)

[8] Chinh L. M., G. Swit, 2015. Application of the acoustic emission method of identification and location of destructive processes to the monitoring of the technical state of pre-stressed concrete bridges. Hội nghị khoa học Công nghẹ Giao thông vận tải lần thú III, năm 2015.

[9] Chinh L. M., Swit G., Adamczak A., Krampikowska A.. 2016. Nhat Tan Bridge - The biggest cable-stayed bridge in Vietnam. Symposium WMCAUS 2016. Czech. Procedia Engineering 161 (2016): 666 - 673.

[10] Chinh L. M.. Swit G.. 2016. A Prototype System for Acoustic Emission-Based Structural Health Monitoring of Mỹ Thuận Bridge. Prognostics \& System Health Management Conference-Chengdu (PHM-2016 Chengdu, China).

\section{Acknowledgments:}

The work was financed by work University, Hanoi, Vietnam, Transportation Department, Civil Engineering Faculty, Thuy

\section{Podziękowania:}

Praca byla finansowana przez Uniwersytet, Hanoi, Wietnam, Wydziat Transportu, Wydziat Inżynierii Ladowej, Thuy 